\title{
PEMBANGUNAN IRIGASI WIDAS DAN PENGARUHNYA TERHADAP EKONOMI DAN LINGKUNGAN DI NGANJUK, JAWA TIMUR 1978-2010
}

\author{
THE DEVELOPMENT OF WIDAS IRRIGATION AND \\ ITS EFFECT ON THE ECONOMY AND ENVIRONMENT \\ OF NGANJUK, EAST JAVA 1978-2010
}

\author{
Ardhian Dwi Prabowo dan Nawiyanto \\ Program Studi Ilmu Sejarah, Fakultas Ilmu Budaya, Universitas Jember, Indonesia \\ Jln. Kalimantan 37, Jember 68121 \\ prabowoardhian@gmail.com; snawiyanto@gmail.com
}

Diterima tanggal 3 Maret 2020

Disetujui tanggal 14 September 2020

\begin{abstract}
The paper discusses Widas irrigation development and effects on the socio-economy and environment of people of Nganjuk Regency in 1978-2010. The research examines the conditional factors promoting Widas irrigation development, the development process and effects on the local economy and environment. The study used the historical method conceptualized by Kuntowijoyo which included topic selction, source collection, verification, interpretation, and historiography. Widas river has offered important benefits for the community's economy, especially the agricultural sector; however, it still causes floods which leads to a big loss to Nganjuk people. The irrigation development was a program designed to bring multiple benefits, particularly to control the severe flood of Widas river and to promote agricultural production in Nganjuk area. It successfully increases agricultural production and improves the community's economy by opening opportunities to change cropping patterns and freshwater fish farming. However, this project has not been able to free Nganjuk community from flooding because the forest damage in the upstream area of Widas river disrupts the hydrological system.
\end{abstract}

Keywords: floods, agricultural economy, Widas irrigation, environment, and Nganjuk.

\begin{abstract}
ABSTRAK
Tulisan ini membahas tentang pembangunan irigasi Widas dan pengaruhnya terhadap kondisi sosial-ekonomi dan lingkungan masyarakat Kabupaten Nganjuk tahun 1978-2010. Permasalahan yang dikaji dalam tulisan ini berkaitan dengan faktor-faktor yang mendorong pembangunan irigasi Widas, proses konstruksi dan pengaruh pembangunan irigasi Widas terhadap kondisi ekonomi dan lingkungan setempat. Metode yang digunakan dalam tulisan ini adalah metode sejarah yang dikonsepsikan oleh Kuntowijoyo, dengan tahapan pemilihan
\end{abstract}


Handep Jurnal Sejarah dan Budaya Vol. 4, No. 1, Desember 2020, hlm. 19-38

topik, pengumpulan sumber, verifikasi, interpretasi, dan historiografi. Sungai Widas memiliki manfaat penting bagi kehidupan ekonomi masyarakat khususnya sektor pertanian, namun keberadaannya sering menghadirkan bencana banjir, yang menyebabkan kerugian besar bagi masyarakat Nganjuk. Pembangunan irigasi Widas merupakan program yang dirancang untuk memberikan manfaat ganda, yakni pengendalian banjir Sungai Widas dan promosi produksi pertanian di kawasan Nganjuk. Pembangunan irigasi Widas berhasil meningkatkan produksi pertanian dan memperbaiki ekonomi masyarakat dengan terbukanya peluang melakukan perubahan pola tanam dan budi daya ikan air tawar, namun proyek ini belum mampu membebaskan masyarakat Nganjuk dari bencana banjir karena terganggunya tata hidrologis akibat kerusakan hutan di kawasan hulu Sungai Widas.

Kata kunci: banjir, ekonomi pertanian, irigasi Widas, lingkungan, dan Nganjuk.

\section{A. PENDAHULUAN}

Jaringan irigasi seringkali hanya diposisikan secara figuratif dan sekunder dalam narasi besar (grand narrative) tentang revolusi hijau. Fokus utama narasi besar revolusi hijau banyak diberikan pada peran teknologi bibit. Terutama berupa varietas padi unggul dan aplikasi sarana produksi berupa bahan-bahan kimia sebagai kunci keberhasilan pelipatgandaan produksi beras (Djatileksono 1987:17; Fox 1997:167-218; Nurhati, Ramdhaniati, dan Zuraida 2008:8-13; Gable dan Springer 2019:83-92). Perhatian akademis juga banyak diarahkan pada implikasi ekonomis dan sosiologis penerapan revolusi hijau di kalangan masyarakat perdesaan (Hayami dan Kikuchi 1987:77; Tjondronegoro 1990:1-14; Nugraheni dan Kumalasari 2017:531-550; Yulia 2019:10-21; Partasasmita et al. 2019:23-36). Kontras dengan aspekaspek tersebut, narasi tentang pembangunan jaringan irigasi jarang menjadi fokus pembahasan akademis. Pada dasarnya pembangunan jaringan irigasi telah terbukti memberikan peran penting dalam rangka meningkatkan produktivitas hasil pertanian khususnya padi di Indonesia (Panuju, Mizuno, dan Trisasongko 2013:27-37).

Oleh karena itu, tulisan ini hendak menggeser pembangunan jaringan irigasi dari posisi ilustratif-pinggiran ke fokus utama pembahasan. Hal ini dipandang penting karena keberhasilan peningkatan produksi padi sangat dipengaruhi oleh sistem pengelolaan air yang tepat melalui jaringan irigasi (Harahap dan Harahap 2018:6-8). Pada tulisan ini kasus yang diangkat adalah jaringan irigasi Sungai Widas di Kabupaten Nganjuk, Jawa Timur. Pembangunan jaringan irigasi Widas merupakan bagian dari program kebijakan Pemerintah Republik Indonesia guna menciptakan swasembada pangan di Indonesia. Pembangunan irigasi Widas juga diharapkan dapat mengatasi krisis pangan yang sering mendera Indonesia sejak proklamasi hingga 1960-an akibat rendahnya produktivitas padi dan pesatnya laju pertumbuhan penduduk 
Indonesia (Nawiyanto 2013:60-73).

Pada konteks lokal Nganjuk, pembangunan irigasi Widas merupakan program yang dirancang untuk mengatasi bencana banjir dan kekeringan yang sering melanda kawasan ini dan meningkatkan produktivitas pertanian.

Berdasarkan penjelasan di atas tulisan ini bertujuan menggambarkan proses pembangunan irigasi Widas dan pengaruhnya terhadap kondisi sosialekonomi dan lingkungan di Kabupaten Nganjuk. Permasalahan yang dikaji dalam tulisan ini adalah (1) mengapa dilakukan pembangunan jaringan irigasi Widas?; (2) bagaimana proses konstruksi jaringan irigasi Widas dilakukan?; (3) apa dampak pembangunan irigasi Widas terhadap kondisi ekonomi dan lingkungan Kabupaten Nganjuk?

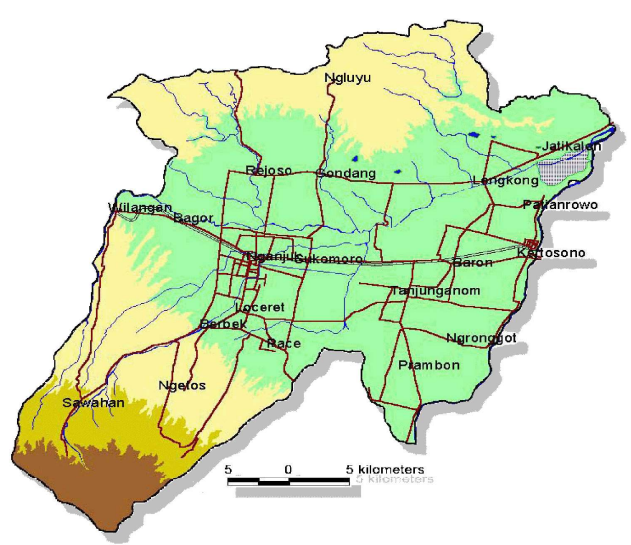

Gambar 1. Peta Wilayah Kabupaten Nganjuk. Sumber: Departemen Pekerjaan Umum, Direktorat Jenderal Sumber Daya Air,

"Laporan Akhir Pekerjaan Studi Sistem Penanggulangan Banjir Kali Widas, Kabupaten Nganjuk oleh PT. Rama Sumber Teknik" 2008:II-3.
Ruang lingkup tulisan ini berfokus pada beberapa aspek yang berkaitan dengan ruang lingkup spasial, temporal, dan kajian. Lingkup spasial tulisan ini adalah Kabupaten Nganjuk, khususnya beberapa kecamatan di sepanjang Daerah Aliran Sungai (DAS) Widas yaitu Kecamatan Wilangan, Bagor, Rejoso, Gondang, Sukomoro, Baron, Lengkong, Patianrowo, dan Jatikalen. Kecamatan-kecamatan tersebut dipilih berkaitan dengan pertimbangan sebagai kawasan yang merasakan dampak secara langsung dari adanya pembangunan irigasi Widas.

Ruang lingkup temporal menggunakan rentang waktu 1978-2010. Pemilihan tahun 1978 berkaitan dengan proses awal pembangunan irigasi Widas dengan pembangunan Bendungan Bening pada Tahun Anggaran 1978/ 1979. Adapun tahun 2010 dipilih menjadi batas akhir berkaitan dengan terjadinya banjir 25 tahunan di DAS Widas. Ruang lingkup kajian dalam tulisan ini adalah sejarah lingkungan. Kajian mengenai sejarah lingkungan dapat dikaitkan dengan empat aspek yaitu: (1) permasalahan lingkungan, (2) perubahan lingkungan, (3) pandangan tentang lingkungan, dan (4) politik lingkungan (Nawiyanto 2012:20-27). Tulisan ini merupakan kajian mengenai perubahan lingkungan yang terjadi akibat keberadaan pembangunan jaringan irigasi Widas di Kabupaten Nganjuk.

Beberapa kajian penting tentang irigasi di Indonesia memang telah dilakukan baik oleh peneliti asing 
Handep Jurnal Sejarah dan Budaya Vol. 4, No. 1, Desember 2020, hlm. 19-38

maupun domestik. Studi Varley (1993) berjudul Masalah dan Kebijakan Irigasi Pengalaman Indonesia memberikan gambaran umum tentang perkembangan jaringan irigasi di Indonesia. Buku ini menguraikan masalah dan kebijakan yang diambil pemerintah pada masa Orde Lama sampai Orde Baru guna menciptakan swasembada beras di Indonesia. Usaha mewujudkan swasembada beras telah dilakukan melalui penerapan Program Kesejahteraan Kasimo pada 1952-1956 hingga penerapan Program Bimas melalui prinsip Panca Usaha pada masa Orde Baru. Program Bimas ini yang kemudian menjadi dasar bagi pembangunan jaringan irigasi di hampir seluruh wilayah Indonesia.

Studi lainnya tentang irigasi di Indonesia juga telah ditulis oleh Ertsen (2005) dengan judul Prescribing Perfection: Emergence of an Engineering Irrigation Design Approach in the Netherlands East Indies and its Legacy 1830-1990. Melalui studi ini, Ertsen menguraikan praktik irigasi kolonial Hindia Belanda. Praktik irigasi tersebut telah menjadi landasan dalam membuat rancangan, regulasi dan pengelolaan jaringan irigasi dalam skema irigasi baru. Landasan irigasi kolonial juga telah menjadi kerangka modernisasi pertanian melalui program revolusi hijau. Studi Ertsen dengan jelas menunjukkan adanya kesinambungan dalam rancangan irigasi dan praktik pengelolaan pada masa kolonial Hindia Belanda dan masa Orde Baru di Indonesia.
Berbeda dengan kajian Varley yang empiris dan Ertsen yang lebih teknis dan historis, studi irigasi dengan nuansa konseptual yang lebih kuat dihasilkan Wirosoedarmo (2017) berjudul Irigasi Pertanian Bertekanan. Buku ini berisi tentang pengembangan jaringan irigasi dan konsep dasar sistem pengelolaan air irigasi guna meningkatkan sektor pertanian. Buku ini juga berisi tentang konsep penting pengelolaan air irigasi yang diharapkan mampu memberikan pemikiran baru, terutama guna memecahkan permasalahan irigasi di masa mendatang bagi keberlangsungan sektor pertanian.

Pembangunan jaringan irigasi di Jawa Timur yang menjadi perhatian serius Pemerintah Orde Baru telah diungkap dalam beberapa studi kasus. Salah satunya adalah studi yang dilakukan Shiamah (2019) yang berjudul Pengaruh Bendungan Wlingi Terhadap Lingkungan dan Ekonomi Masyarakat di Sepanjang Saluran Irigasi Lodoyo Tulungagung Tahun 1970-1990. Tulisan ini membahas mengenai dampak pembangunan Bendungan Wlingi dalam peningkatan produksi pangan, pengendalian sedimentasi aliran Sungai Brantas akibat letusan Gunung Kelud, dan penyediaan hidropower.

Pembangunan jaringan irigasi baru yang berguna untuk meningkatkan potensi pertanian dan sistem pengendali banjir juga kembali dilakukan di wilayah Jawa Timur melalui pembangunan Bendungan Wonorejo. Pembangunan Bendungan Wonorejo 
ini telah dibahas dalam studi Mardiyah (2016) berjudul Pembangunan Waduk Wonorejo, Kabupaten Tulungagung Tahun 19822002. Tulisan ini lebih menekankan proses pembangunan bendungan dalam konsep pendekatan ekonomi, namun memberikan gambaran mengenai dampak pembangunan bagi peningkatan hasil pertanian di Jawa Timur, khususnya Kabupaten Tulungagung.

Adapun kajian yang memiliki kesamaan objek penelitian tentang Sungai Widas telah dihasilkan oleh Kasiyanti, Nugroho, dan Dwijoyanto (2012) yang berjudul Kajian Penanggulangan Banjir Kali Widas Kabupaten Nganjuk Provinsi Jawa Timur. Tulisan ini membahas penanggulangan banjir Kali Widas dalam konteks analisis hidrologis dengan menggunakan pendekatan empat macam hidrograf satuan sintetik. Analisis tulisan ini lebih mengutamakan perhitungan hidrograf guna memperkirakan ulang volume tampungan air guna mengatasi bencana banjir akibat luapan Kali Widas.

Studi-studi yang telah dilakukan sebelumnya berguna untuk memperkuat narasi mengenai pembangunan jaringan irigasi di Kabupaten Nganjuk melalui pembangunan irigasi Widas. Tulisan-tulisan tersebut dianggap penting dalam memberikan wawasan umum tentang perkembangan historis dan empiris tentang jaringan irigasi dalam lingkup nasional. Kajian di atas juga dapat memberikan inspirasi dan model eksplanasi dalam mengungkapkan aspek tertentu yang belum diungkapkan dari adanya pembangunan jaringan irigasi. Terlebih dalam setiap wilayah memiliki permasalahannya sendiri, sehingga penanganannya juga berbeda.

Inspirasi teoretis yang mendasari pembahasan tulisan ini diambil dari teori transformasi ekosistem yang dikembangkan oleh Goldblatt (2015). Menurut konsepsi Goldblatt, untuk memahami dengan baik transformasi ekosistem perlu mempertimbangkan empat konsep yang saling berhubungan satu sama lain. Konsep tersebut meliputi sebab-sebab langsung dan tidak langsung dari perubahan, dampak-dampak ekologis-material, dan implikasi sosialnya. Kerangka teoretis tersebut akan dikombinasikan dengan perspektif genetis agar dapat menghadirkan narasi tentang proses sebagai karakteristik utama tulisan sejarah.

\section{B. METODE}

Tulisan ini merupakan hasil penelitian sejarah dan dikerjakan menggunakan metode sejarah. Menurut Kuntowijoyo (2005), tahapan metode sejarah terdiri atas lima tahapan utama yaitu: pemilihan topik, pengumpulan sumber, verifikasi, interpretasi, dan penulisan.

Pertama, pemilihan topik penelitian dengan fokus pembangunan irigasi Widas dan pengaruhnya terhadap ekonomi dan lingkungan dilakukan dengan pertimbangan subjektif dan objektif. Secara subjektif, topik ini dipilih karena bersesuaian dengan 
Handep Jurnal Sejarah dan Budaya Vol. 4, No. 1, Desember 2020, hlm. 19-38

minat intelektual peneliti. Secara objektif, topik ini menarik karena merupakan peristiwa yang mempunyai signifikansi yang tinggi untuk diteliti. Adapun kriteria untuk menentukan kelayakan peristiwa masa lampau diangkat dalam penulisan sejarah yaitu ketersediaan sumber sejarah yang memadai dan dapat dijangkau (Herlina 2020:86-87). Tidak diragukan lagi, pembangunan irigasi Widas berpengaruh besar bagi kehidupan masyarakat Nganjuk dan berbagai konsekuensinya dirasakan hingga beberapa dekade kemudian.

Kedua, pengumpulan sumber yaitu proses pengumpulan sumber-sumber dan bahan-bahan tertulis, tercetak, dan lisan yang relevan dengan topik penelitian. Sumber sejarah yang digunakan meliputi dua jenis yaitu sumber primer dan sekunder. Sumber primer yang digunakan mencakup arsip dan dokumen publikasi yang diperoleh dari beberapa lembaga dan dinas terkait.

Sumber yang diperoleh dari Dinas Perpustakaan dan Kearsipan Provinsi Jawa Timur di Surabaya ialah surat kabar Kompas tanggal 1 Januari 1979 dan 10 Januari 1979. Penulis memperoleh dokumen publikasi tentang proyek pengembangan wilayah Kali Widas pada 1987 di Perum Jasa Tirta I. Hasil dari pencarian di Balai Besar Wilayah Sungai Brantas ialah beberapa dokumen publikasi, seperti dokumen penawaran pekerjaan normalisasi Kali Widas pada 2003, Flood Report the Widas River
Basin pada 1 Januari 1979, dan dokumen pelaksanaan pekerjaan studi pengukuran kapasitas genangan pada 1985. Adapun di Perpustakaan STIKOSA AWS Surabaya diperoleh sumber berupa surat kabar Surabaya Post tanggal 26 Oktober 1983 dan tanggal 10 November 1983.

Pengumpulan sumber primer juga dilakukan dengan metode sejarah lisan. Peneliti sendiri menggali informasi yang tersimpan dalam memori/ingatan para pelaku dan saksi sejarah yang masih hidup. Sumber informasi lisan digali antara lain dari (1) Agus Santoso selaku juru air Bendungan Bening; (2) Prianto selaku juru pengadaan sumber daya air Bendungan Bening; dan pelaku pekerjaan Pelurusan Sungai Widas. Pencarian sumber sekunder dilakukan dengan studi pustaka di Perpustakaan Universitas Jember dan dinas-dinas terkait di Kabupaten Nganjuk.

Ketiga, verifikasi yaitu proses pemilahan sumber dan bahan sejarah yang telah didapat dari langkah pengumpulan sumber. Tahapan verifikasi meliputi kritik eksternal dan kritik internal. Kritik eksternal dilakukan untuk mendapatkan sumber sejarah yang otentik. Kritik internal diterapkan untuk mendapatkan informasi yang kredibel untuk ditetapkan sebagai fakta-fakta sejarah.

Keempat, tahap interpretasi yaitu proses menafsirkan dan menyimpulkan kesaksian-kesaksian sejarah yang kredibel dari sumber-sumber yang otentik. Pada tahap interpretasi, peran pendekatan dan teori berfungsi sebagai 
alat untuk menganalisis maupun menjelaskan suatu peristiwa. Tahap interpretasi terdiri atas tahap analisis dan sintesis.

Kelima, historiografi yaitu penyusunan narasi dan eksplanasi mengenai masa silam. Historiografi merupakan tahapan penulisan kembali hasil interpretasi dengan merangkai fakta-fakta menjadi konstruksi sejarah yang memenuhi kaidah dan pertanggungjawaban ilmiah.

\section{HASIL DAN BAHASAN}

\section{Hidup dalam Belitan Krisis}

Nganjuk adalah kawasan di Jawa Timur yang rawan bencana hidrometeorologis berupa banjir dan kekeringan. Keberadaan Sungai Widas tidak jarang menyebabkan banjir karena volume aliran airnya yang tidak tertampung. Pada 1960 banjir Sungai Widas telah menenggelamkan sebagian wilayah Nganjuk dan menimbulkan korban jiwa. Pada 1966 banjir akibat luapan Sungai Widas kembali terjadi yang menghancurkan bangunan dam dan tanggul sungai. Permukiman dan lahan pertanian diterjang aliran air dan terendam genangan. Rehabilitasi tangkis telah dilakukan di beberapa bagian Sungai Widas, misalnya di Kecamatan Lengkong. Namun upaya ini belum mampu mengatasi secara tuntas ancaman banjir yang disebabkan luapan Sungai Widas (Sindhunoto dan Margiono 10 Januari 1979:9).

Kontras dengan terjangan banjir pada musim hujan, aliran air Sungai Widas cepat menyusut pada musim kemarau. Keberadaan sungai ini tidak mampu menyediakan pasokan irigasi. Keterbatasan volume aliran air Sungai Widas menyebabkan sebagian besar lahan pertanian wilayah Nganjuk mengalami kekeringan. Kurangnya pasokan irigasi pada tahun 1976 menyebabkan kekeringan sekitar 21.000 hektar lahan pertanian di bagian utara Nganjuk. Walaupun di sebagian wilayah telah terjamin kebutuhan irigasi sepanjang musim, namun kondisi ini hanya berlaku pada sekitar 15.000 hektar atau 40\% dari total area sawah. Upaya mengatasi kekeringan dan kekurangan pasokan air irigasi di DAS Widas telah dilakukan dengan membangun sekitar 250 sumur. Program "sumurisasi" ini hanya mampu memenuhi kebutuhan irigasi untuk lahan sawah sekitar 3.000 hektar dan masih terdapat 21.000 hektar sawah yang tidak terjamin irigasinya (Departemen Pekerjaan Umum 1976:12-15).

Bencana yang sering melanda kawasan Nganjuk baik banjir maupun kekeringan berdampak besar terhadap sektor pertanian. Produktivitas pertanian di kawasan Nganjuk tergolong rendah dibandingkan dengan kawasan lain di Jawa Timur. Pada tahun 1955 hasil padi per kapita untuk wilayah Nganjuk sebesar 108 kg. Angka tersebut lebih rendah dibanding Kediri dan Blitar yang masing-masing sebesar $110 \mathrm{~kg}$ (Reksohadiprodjo dan Hadisapoetra 1986:324). Pada 1970 produksi padi di Kabupaten Nganjuk, dari total luas lahan panen sekitar 
Handep Jurnal Sejarah dan Budaya Vol. 4, No. 1, Desember 2020, hlm. 19-38

39.000 hektar, hanya dapat memproduksi padi rata-rata mencapai 32,58 kuintal/hektar. Angka ini berbanding terbalik dengan wilayah Karesidenan Kediri yang lain. Di Kabupaten Tulungagung dengan luas lahan panen mencapai 19.300 hektar, dapat memproduksi padi rata-rata sebesar 38,93 kuintal/hektar (Kantor Sensus dan Statistik Provinsi Jawa Timur 1971:40).

Kehidupan yang sering terancam bencana hidrometeorologis dan produksi pertanian yang masih relatif rendah mendorong dilakukan upayaupaya pencarian jalan keluar. Pembangunan irigasi Widas dipandang mampu menjadi program yang menjanjikan dua manfaat sekaligus yaitu manfaat lingkungan dan ekonomi bagi masyarakat kawasan Nganjuk. Bagian berikut secara jelas akan menguraikan proses pelaksanaan proyek irigasi Widas.

\section{Pembangunan Irigasi Widas}

Pembangunan irigasi Widas dianggap penting keberadaannya oleh Pemerintah Republik Indonesia guna menanggulangi ancaman kekeringan dan banjir di Kabupaten Nganjuk. Pada 1973 dilakukan studi kelayakan oleh Proyek Pengembangan Wilayah Sungai (PPWS) Brantas dengan bantuan teknis dari Overseas Technical Cooperation Agency (OTCA) dari Pemerintah Jepang di aliran Sungai Widas dan Ngrowo. Pelaksanaan pembangunan irigasi Widas diserahkan Pemerintah Republik Indonesia kepada Dewan Eksekutif Proyek Brantas
(Proyek Brantas) di Malang pada 1975. Adapun pelaksanaan proyek irigasi Widas dimulai dengan pembangunan Bendungan Bening dan sarana irigasinya pada tahun anggaran 1978/ 1979.

Pada September 1975 Proyek Brantas telah menyiapkan laporan studi tentang proyek yang bertujuan untuk mempromosikan proyek ke realisasi awal. Studi kelayakan mengenai proyek irigasi juga dilaksanakan oleh Dewan Eksekutif Proyek Serbaguna Brantas pada Oktober 1975. Pada pelaksanaan studi kelayakan dilakukan kerja sama antara Proyek Brantas dengan Dinas Irigasi Provinsi Jawa Timur pada Oktober 1975 hingga 1976 (Departemen Pekerjaan Umum 1976: 9-10). Pada 1977 pembangunan Bendungan Bening dilaksanakan dengan pekerjaan pembuatan terowongan pengalihan. Pembuatan terowongan bertujuan untuk mengalihkan sementara aliran Sungai Bening agar tidak mengganggu pelaksanaan pembangunan tanggul bendungan utama. Proses pembangunan fisik Bendungan Bening mulai dilaksanakan pada tahun anggaran 1978/1979 dengan menggunakan dana APBN dan dana pinjaman luar negeri. Adapun lokasi pembangunan Bendungan Bening berada di lahan Perhutani Kesatuan Pemangkuan Hutan (KPH) Saradan Perum Perhutani Unit II Jawa Timur dengan menggunakan sistem pinjam lahan. 
Pelaksanaan pembangunan

Bendungan Bening dan sarana irigasinya dikerjakan secara langsung oleh Proyek Brantas sebagai kontraktor pembangunan dan dibantu oleh Nippon Koei Co. Ltd sebagai konsultan desain pekerjaan (Departemen Pekerjaan Umum 1995:208). Proses pengadaan peralatan konstruksi dilaksanakan dengan menggunakan sistem force account. Penggunaan sistem tersebut memungkinkan pengadaan sebagian besar peralatan dari pembangunan proyek lain, seperti Proyek Tahap 2 Karangkates dan Proyek Serbaguna Wlingi. Pada 1979 pembangunan Bendungan Bening dilanjutkan dengan pembangunan Bendung Glatik dan Ngudikan di DAS Widas. Pembangunan bendung tersebut bertujuan untuk mengoptimalkan distribusi pasokan air irigasi menuju bagian utara dan selatan Widas. Pekerjaan juga dilanjutkan dengan pembangunan beberapa daerah pengairan di DAS Widas meliputi Daerah Pengairan Rejoso, Lengkong, Senggowar, Kedungmaron, Kedunggupit, dan Ngudikan.

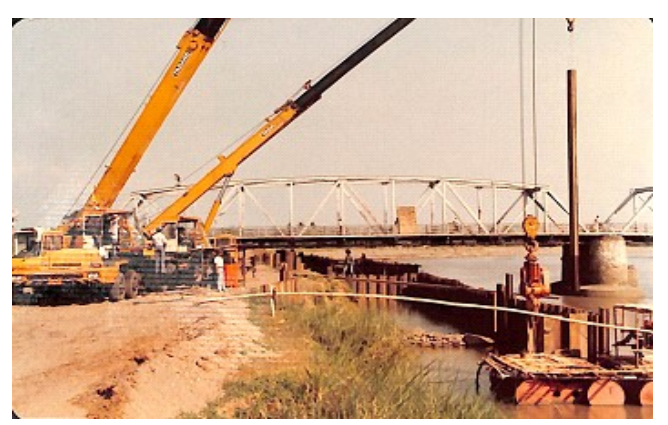

Gambar 2. Pembangunan Bendungan Bening. Sumber: Dinas Perpustakaan dan Kearsipan Provinsi Jawa Timur.
Pada 27 April 1982 dilaksanakan peresmian pembangunan tahap I oleh Presiden Soeharto dengan pembukaan pintu air Bendungan Bening menuju layanan irigasi di Kabupaten Nganjuk (Wawancara, Santoso, Madiun, 19 November 2019). Guna mendukung fungsi irigasi Widas, maka pada 28 Oktober 1983 dilakukan peresmian beberapa mesin pompa air di aliran irigasi Widas oleh Menteri Pekerjaan Umum, Ir. Suyono Sosrodarsono. Peresmian mesin pompa terdiri atas sebelas gardu pompa yang terletak di Kecamatan Wilangan, Bagor, Rejoso, dan Gondang (Anon, Oktober 1983:16). Adapun total biaya yang dihabiskan dalam proses pembangunan tersebut mencapai US\$19.842.600 yang terdiri atas US\$12.707.000 berasal dari dana APBN dan sisanya sebesar US\$7.135.600 berasal dari dana pinjaman luar negeri (Departemen Pekerjaan Umum 1976:44).

\section{Membedah Sungai Widas}

Pada 1 Januari 1979 di Kabupaten Nganjuk telah terjadi banjir besar yang diakibatkan kenaikan debit air Sungai Widas menjadi $1.680 \mathrm{~m}^{3} /$ detik, padahal daya tampung airnya hanya mencapai $680 \mathrm{~m}^{3} /$ detik (Anon, 1 Januari 1979:9). Banjir telah mengakibatkan terganggunya aktivitas perekonomian masyarakat di sembilan kecamatan dan 49 desa di Kabupaten Nganjuk. Banjir telah mengakibatkan tergenangnya infrastruktur, seperti permukiman, jembatan, tanggul, dan akses jalan. 
Handep Jurnal Sejarah dan Budaya Vol. 4, No. 1, Desember 2020, hlm. 19-38

Banjir juga telah menimbulkan kerugian yang disebabkan kerusakan tanaman padi Bimas dan Inmas di beberapa kecamatan. Kerusakan padi telah menimbulkan kerugian bagi petani yang cukup besar, yaitu kerugian padi Bimas mencapai Rp67.638.900,00 dan padi Inmas mencapai Rp9.616.500,00 (Departemen Pekerjaan Umum 1979:15). Banjir di DAS Widas juga telah memengaruhi penurunan hasil produksi padi di Kabupaten Nganjuk pada 1983. Menurut Bupati Nganjuk, Ibnoe Salam, pada 1982 Kabupaten Nganjuk dapat menghasilkan beras mencapai 23.000 ton, namun pada 1983 produksi turun menjadi 5.000 ton (Anon November 1983:4).

Guna mengatasi ancaman banjir di sepanjang DAS, maka perlu diadakan pengelolaan DAS dengan baik dan benar untuk mengurangi kondisi kritis (Abdoellah 2017:134). Pengelolaan DAS dilakukan dengan pekerjaan pelurusan dan pengembangan Sungai Widas guna mengatasi banjir di sepanjang DAS Widas. Pemerintah Indonesia dan Proyek Brantas telah melakukan kerjasama dengan Japan International Corporation Agency (JICA) dari Pemerintah Jepang untuk melakukan studi kelayakan dalam rangka pengembangan Sungai Widas. Pada 1986 studi kelayakan pengembangan Sungai Widas telah selesai dilaksanakan oleh JICA dengan berbagai pekerjaan investigasi dan survei tanah. Studi kelayakan oleh JICA telah menghasilkan beberapa poin mengenai pengembangan Sungai Widas meliputi (1) pembuatan sistem pengendalian banjir dengan melakukan pelurusan aliran sungai dan pembangunan daerah penampungan banjir (daerah retardasi) di Sungai Ulo, Kedungsoko, dan muara Sungai Widas; (2) pembuatan dam dan jaringan irigasi di wilayah Widas Timur (Departemen Pekerjaan Umum 1987:2-3).

"Pelaksanaan pengendalian banjir Sungai Widas melalui pelurusan aliran sungai dilakukan dengan menggunakan dana yang diperoleh dari Asian Development Bank (ADB) untuk Proyek Irigasi Waru-Turi. Pelurusan aliran sungai dilaksanakan dari muara Sungai Widas sampai pertemuannya dengan Sungai Kedungsoko sampai Dam Malangsari dengan panjang mencapai $21 \mathrm{~km}$," jelas Prianto di Madiun pada 20 November 2019. Adapun konsultan desain dalam pengendalian banjir diserahkan kepada Sinotech Engineering Consultants Inc. dari Taipei yang bekerja sama dengan PT Necon Cipta Jasa dari Jakarta. Adapun detail desain pekerjaan dituangkan dalam kontrak No. HK.02.03.01.B.43/CES/84, Loan No.581 INO, dengan detail desain pekerjaan dapat diselesaikan pada Desember 1986 (Departemen Pekerjaan Umum 1987:2-3). Pekerjaan awal pelurusan sungai dilakukan dengan pembebasan lahan seluas 300 hektar. Pada periode 1987 sampai 1988 telah dilaksanakan pembebasan lahan seluas 100 hektar. Adapun untuk sisanya menunggu penyampaian uang 
ganti rugi yang dijadwalkan dilaksanakan pada Oktober sampai November 1988 (Kaharuddin 1988:9).

Pekerjaan fisik pelurusan Sungai Widas dilaksanakan selama empat periode anggaran, yaitu tahun anggaran 1987/1988 sampai tahun anggaran 1990/1991. Adapun tahapan pekerjaan pelurusan aliran sungai meliputi pengerukan dan penggalian tanah, penimbunan tanggul, pembuatan gabion matras, pembangunan jembatan, gorong-gorong, pintu air, serta pelimpah samping di Sungai Kedungsoko dan Widas. Pada proses pelurusan Sungai Widas telah menghabiskan biaya sebesar 18 miliar rupiah. Biaya tersebut berasal dari dana pinjaman dari ADB sebesar US\$7.500.000 atau 13,5 miliar rupiah, dan sisanya berasal dari dana APBN sebesar 4,5 miliar rupiah. Biaya tersebut hanya meliputi untuk pekerjaan utama saja, sehingga tidak termasuk untuk biaya pembebasan lahan, administrasi, pajak spare part, dan engineering service (Departemen Pekerjaan Umum 1987:10).

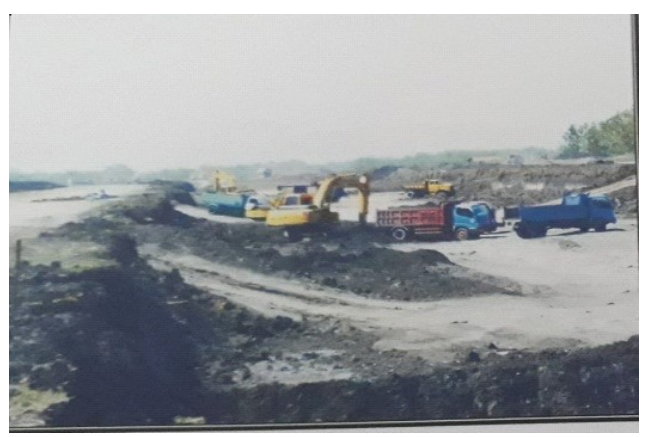

Gambar 3. Pekerjaan Penggalian Tanah Pelurusan Sungai Widas.

Sumber: Balai Besar Wilayah Sungai Brantas (BBWS) 2003.
Guna mendukung pekerjaan pelurusan Sungai Widas agar dapat berfungsi secara optimal dalam mengatasi banjir di Kabupaten Nganjuk, maka dilakukan kembali pekerjaan pembangunan kanal banjir. Pekerjaan tersebut diserahkan kepada beberapa kontraktor lokal, seperti CV Noer Mawar Melati, CV Jaya, dan CV Inneco Wish. Adapun untuk beberapa pekerjaan dikerjakan secara langsung oleh Proyek Pengelolaan Sumber Air dan Pengendali Banjir Brantas (Berita Acara Pemeriksaan untuk Penerimaan Pekerjaan Tahap I No. PSAPB.10/BA-PN/97). Pembangunan kanal banjir secara keseluruhan dilaksanakan dengan menggunakan dana APBN. Pembangunan kanal banjir tersebut meliputi pekerjaan pembuatan galian dan perbaikan talang air BKA di Desa Siwalan Kecamatan Bagor, pembangunan saluran banjir Sungai Widas di Desa Ngerengket, pembuatan talang air di muara Sungai Widas, dan pekerjaan normalisasi dan pembuatan drain outlet Sungai Widas (CV. Inneco Wish 2003:1-2). Pada 2008 banjir kembali terjadi di Kabupaten Nganjuk yang disebabkan luapan anak Sungai Widas, yaitu Sungai Kuncir dan Sungai Semantok. Banjir disebabkan oleh kerusakan hutan di hulu sungai, sehingga guna mengatasi terjadinya banjir di DAS Widas, maka dilakukan kembali pekerjaan pengendalian banjir di DAS Widas (Departemen Pekerjaan Umum 2008:II-19). Pekerjaan dilakukan secara bertahap yang memprioritaskan bagian tengah 
Handep Jurnal Sejarah dan Budaya Vol. 4, No. 1, Desember 2020, hlm. 19-38

sungai utama. Hal tersebut mengatasi kenaikan debit air yang berasal dari anak sungai di bagian utara dan selatan.

\section{Pengaruh Sosial-Ekonomi dan Lingkungan \\ a. Produksi pertanian}

Pembangunan irigasi Widas telah memberikan dampak positif bagi pelaksanaan Program Intensifikasi Serat Karung Rakyat (Iskara), perubahan pola tanam, peningkatan luas lahan pertanian dan hasil produksi pertanian, serta sektor perikanan di Kabupaten Nganjuk. Pembangunan irigasi Widas telah memengaruhi produksi tanaman serat di Kabupaten Nganjuk melalui Program Iskara dengan penanaman tanaman kenaf atau Hibiscus canabinus. Pembudidayaan tanaman kenaf yang merupakan jenis tanaman serat sudah dikerjakan di Indonesia sejak musim tanam 1986/ 1987. Adapun pelaksanaan Program Iskara di Kabupaten Nganjuk dimulai pada masa tanam 1988/1989 dengan dipilihnya kabupaten tersebut menjadi wilayah pengembangan tanaman kenaf. Selain itu Kabupaten Nganjuk juga terpilih menjadi wilayah inventarisasi untuk mencatat jenis hama yang menyerang tanaman kenaf di Provinsi Jawa Timur. Hasil pengamatan menunjukkan terdapat enam belas spesies hama yang menyerang tanaman kenaf di Kabupaten Nganjuk pada 1989 (Sunarto, Soetopo, dan Sujak 2009:1).

Penanaman kenaf di Kabupaten Nganjuk tersebar pada beberapa daerah retardasi di sepanjang DAS Widas, seperti Daerah Retardasi Sungai Ulo, Sungai Kedungsoko, dan muara Sungai Widas. Di Daerah Retardasi Sungai Ulo luas lahan untuk penanaman kenaf mencapai 630 hektar, sedangkan di Daerah Retardasi Sungai Kedungsoko seluas 650 hektar. Adapun di Daerah Retardasi muara Sungai Widas seluas 1.320 hektar, sehingga total keseluruhan lahan kenaf di Kabupaten Nganjuk mencapai 2.600 hektar (Departemen Pekerjaan Umum 1987:4). Pada 1990 komoditas kenaf menjadi salah satu tanaman unggulan yang sering ditanam pada lahan tadah hujan di Kecamatan Sukomoro, Patianrowo, dan Jatikalen. Penanaman kenaf juga dipengaruhi oleh adanya peningkatan permintaan produksi serat sebagai bahan karung goni dan interior mobil. Di Kecamatan Sukomoro, penanaman kenaf sebagian besar dilakukan di Desa Kedungsoko yang merupakan wilayah rawa sungai dan lokasi pembangunan daerah retardasi. Adapun di Kecamatan Patianrowo, penanaman kenaf lebih difokuskan pada Desa Bukur, sedangkan di Kecamatan Jatikalen berada di Desa Ngasem. Hal ini dipengaruhi oleh kondisi di dua desa tersebut yang lahan sawahnya cenderung berawa akibat adanya Daerah Retardasi muara Sungai Widas.

Pembudidayaan kenaf di Kabupaten Nganjuk sebagian besar menggunakan sistem tumpang sari antara kenaf dan jagung. Pada 1990 penerapan sistem tumpang sari telah berdampak pada peningkatan pen- 
dapatan petani mencapai Rp509.000,00 sampai Rp546.000,00 per hektar. Di Kecamatan Sukomoro penggunaan sistem tumpang sari kenaf-jagung juga telah memberikan peningkatan hasil produksi tanaman tersebut. Produksi kenaf dapat mencapai 2,235 ton/hektar dan produksi jagung mencapai 2.978 ton/hektar. Hal tersebut berbeda apabila menggunakan sistem monokultur. Produksi dan keuntungan yang didapatkan petani yang menggunakan sistem monokultur tidak begitu besar (Santoso dan Sastrosupadi 1991:1-7). Di Desa Bukur, Kecamatan Patianrowo, penggunaan sistem tumpang sari kenafjagung telah berhasil meningkatkan hasil produksi dan pendapatan para petani. Sistem tumpang sari kenafjagung dapat menghasilkan kenaf mencapai $2.300 \mathrm{~kg} /$ hektar dan jagung mencapai $2.540 \mathrm{~kg} /$ hektar, sehingga pendapatan yang dihasilkan mencapai Rp6.505.000,00 per hektar (Santoso, Sastrosupadi, dan Supriyadi 2001:2-9).

Pembangunan bendungan dan pelurusan Sungai Widas telah memberikan dampak pada peningkatan produksi ikan air tawar di Kabupaten Nganjuk. Pada 1992 produksi ikan air tawar di Kabupaten Nganjuk mencapai $752.140 \mathrm{~kg}$ yang berasal dari budi daya kolam, waduk, sungai, dan rawa sungai. Adapun produksi terbesar ikan dari sungai terjadi pada tahun 2003 yang dapat memproduksi sekitar $308.125 \mathrm{~kg}$. Pada 2004 budi daya waduk dapat memproduksi ikan dalam jumlah terbesar yakni $171.000 \mathrm{~kg}$ (Badan Pusat Statistik Kabupaten Nganjuk
2006:181). Peningkatan tersebut tidak lepas dari keberhasilan pembangunan bendungan dan pelurusan Sungai Widas dalam menjaga debit air sungai, sehingga menciptakan tempat guna perkembangbiakan dan budi daya ikan. Ketersediaan pasokan air irigasi juga telah memengaruhi penerapan sistem mina padi di Kabupaten Nganjuk, termasuk di Kecamatan Nganjuk dan Bagor. Walaupun demikian, peningkatan produksi ikan di Kabupaten Nganjuk masih dianggap rendah karena masih belum dapat memenuhi target konsumsi ikan per kapita nasional pada 2005. Konsumsi ikan per kapita di Kabupaten Nganjuk hanya mencapai $13,06 \mathrm{~kg}$, sedangkan target nasional mencapai $26 \mathrm{~kg}$ (Badan Pusat Statistik Kabupaten Nganjuk 2006:201).

Pembangunan irigasi Widas juga telah memengaruhi perubahan pola tanam di beberapa daerah pengairan DAS Widas. Di Daerah Pengairan Senggowar, intensitas penanaman padi yang awalnya hanya 1 kali per tahun, setelah pembangunan mengalami peningkatan intensitas penanaman menjadi dua sampai tiga kali per tahun. Kondisi tersebut terjadi pula di Daerah Pengairan Ngudikan. Perubahan pola tanam dipengaruhi oleh ketersediaan pasokan air yang dapat mencukupi kebutuhan air irigasi sepanjang musim di DAS Widas.

Pada 2002 di Daerah Pengairan Senggowar telah mengalami peningkatan pendapatan petani dari adanya perubahan pola tanam. Peningkatan 
Handep Jurnal Sejarah dan Budaya Vol. 4, No. 1, Desember 2020, hlm. 19-38

tersebut terjadi karena penerapan pola padi-padi-padi yang dapat menghasilkan keuntungan mencapai Rp40.167.000,00 per tahun (Rahayu, Wirasoedamono, dan Suharto 2015:322).

Perubahan pola tanam juga telah memberikan dampak pada peningkatan hasil produksi pertanian di Kabupaten Nganjuk, terutama padi dan jagung. Pada periode 2004 sampai 2005 terjadi kenaikan hasil produksi padi mencapai 2,97\%, yang awalnya sekitar 3.902.318,73 kuintal naik menjadi 4.021.786,05 kuintal. Kenaikan juga terjadi pada komoditas jagung yang awalnya mencapai 1.453.694,85 kuintal naik menjadi 1.851.301,09 kuintal (Badan Pusat Statistik Kabupaten Nganjuk 2006:141). Pada 2005 di Kabupaten Nganjuk hanya dapat memproduksi padi rata-rata mencapai 62,41 kuintal/hektar. Jumlahnya masih relatif lebih rendah dibandingkan dengan wilayah di sepanjang DAS Widas yang dapat memproduksi padi rata-rata mencapai 64,56 kuintal/hektar. Kondisi tersebut menunjukkan keberadaan irigasi Widas telah berhasil meningkatkan produksi pertanian, mengatasi banjir serta kekeringan di wilayah tersebut. Pada periode 2007 sampai 2008 produksi padi kembali mengalami peningkatan sekitar $2,16 \%$, dari awalnya sebesar 4.053.083 kuintal naik menjadi 4.140.981,89 kuintal. Adapun peningkatan produksi tersebut masih didominasi oleh wilayah-wilayah di sepanjang DAS Widas yang meliputi
Kecamatan Sukomoro, Lengkong, dan Gondang (Badan Pusat Statistik Kabupaten Nganjuk 2009:155). Kondisi tersebut tidak lepas dari peningkatan luas lahan sawah teknis setelah adanya pembangunan irigasi Widas yang telah berhasil meningkatkan jumlah produksi pertanian. Adapun luas penggunaan lahan di DAS Widas dapat dilihat pada Tabel 1.

\begin{tabular}{rlr} 
No. & Penggunaan Lahan & \multicolumn{1}{c}{ Luas (ha) } \\
1 & Sawah Irigasi Teknis & $29.399,91$ \\
2 & Sawah Tadah Hujan & $2.278,24$ \\
3 & Semak Belukar & $1.967,16$ \\
4 & Permukiman & $19.432,59$ \\
5 & Perkebunan & $9.601,12$ \\
6 & Hutan & $83.021,00$ \\
7 & Rumput/Tanah & 133,10 \\
& Kosong & \\
8 & Tegalan/Ladang & $3.000,00$ \\
9 & Rawa & $1.367,73$ \\
& $\quad$ Jumlah & $\mathbf{1 5 0 . 2 0 0 , 8 5}$
\end{tabular}

Tabel 1. Penggunaan Lahan di Sepanjang DAS pada 2008. Sumber: Departemen Pekerjaan Umum Direktorat Jenderal Sumber Daya Air, "Laporan Akhir Pekerjaan Studi Sistem Penanggulangan Banjir Kali Widas, Kabupaten Nganjuk oleh PT. Rama Sumber Teknik" 2008:II-8.

Tabel 1 menunjukkan di sepanjang DAS Widas telah mengalami peningkatan penggunaan lahan untuk aktivitas pertanian mencapai 27,1\%. Awalnya sebesar 8.600 hektar, lalu mulai mengalami kenaikan menjadi $31.678,15$ hektar pada 2008. Luas lahan 
sawah tersebut meliputi lahan sawah irigasi teknis mencapai 29.399,91 hektar dan sawah tadah hujan mencapai 2.278,24 hektar.

Keberadaan irigasi Widas juga telah memengaruhi penanaman komoditas bawang merah di sepanjang DAS Widas. Pada 2008 di Kabupaten Nganjuk dapat memproduksi bawang merah mencapai 80.346 ton dengan sebagian besar terkonsentrasi di wilayah sepanjang DAS Widas (Badan Pusat Statistik Kabupaten Nganjuk 2009:158). Adapun di wilayah Widas dapat memproduksi bawang merah sebesar 79.648,5 ton atau 99\% dari total keseluruhan di Kabupaten Nganjuk. Kondisi tersebut tidak lepas dari ketersediaan pasokan air irigasi di DAS Widas, sehingga memungkinkan penanaman bawang merah pada musim kemarau.

\section{b. Lingkungan}

Pembangunan irigasi Widas telah berdampak besar bagi kondisi lingkungan di Kabupaten Nganjuk yang awalnya sering terjadi banjir dan kekeringan. Pelurusan Sungai Widas telah berhasil mengurangi ancaman banjir di wilayah sepanjang DAS Widas, tetapi banjir tidak sepenuhnya dapat diatasi. Hal tersebut disebabkan terdapat beberapa lokasi yang tetap mengalami genangan air akibat kenaikan debit Sungai Widas. Wilayah tersebut berada di sekitar daerah retardasi DAS Widas yang meliputi
Daerah Retardasi Sungai Ulo, Sungai Kedungsoko, dan muara Sungai Widas. Kondisi tersebut didasarkan pada Laporan Pelaksanaan Pekerjaan Studi Pengukuran Kapasitas Genangan yang dilakukan JICA (Japan International Cooperation Agency). Laporan tersebut menunjukkan genangan air tetap terjadi di daerah retardasi disebabkan oleh banjir 5 tahunan, 10 tahunan, dan 25 tahunan Sungai Widas (Departemen Pekerjaan Umum 1985:V-1).

Pembangunan irigasi Widas juga telah memberikan dampak positif dalam menanggulangi perluasan lahan kritis di Kabupaten Nganjuk. Perluasan lahan kritis merupakan salah satu faktor yang menghambat aktivitas dan produktivitas tanaman pertanian di Kabupaten Nganjuk. Pada 2009 telah terjadi penurunan lahan kritis di Kabupaten Nganjuk menjadi 9.105 hektar. Adapun sebelum pembangunan irigasi Widas, luas lahan kritis di Kabupaten Nganjuk mencapai 38.800 hektar, termasuk di daerah Widas yang mencapai 54\% atau 21.000 hektar (Departemen Pekerjaan Umum 1976:14-15). Setelah pembangunan irigasi Widas luas lahan kritis di daerah Widas dapat dikurangi sebesar 91\% dengan menyisakan lahan kritis mencapai 1.925 hektar. Adapun luas dan sebaran lahan kritis di DAS Widas pada 2009 dapat dilihat pada Tabel 2. 
Handep Jurnal Sejarah dan Budaya Vol. 4, No. 1, Desember 2020, hlm. 19-38

\begin{tabular}{llrrrr} 
No & Kecamatan & \multicolumn{2}{c}{ Tingkat Kekritisan } & Jumlah \\
Angka & Potensial & \\
Kritis (ha) & \multicolumn{1}{c}{ (ha) } & \\
1 & Wilangan & 305 & - & 305 \\
2 & Bagor & 240 & - & 240 \\
3 & Lengkong & 391 & - & 391 \\
4 & Jatikalen & 426 & - & 426 \\
5 & Rejoso & 238 & - & 238 \\
6 & Gondang & 150 & 175 & 325 \\
& Jumlah & $\mathbf{1 . 7 5 0}$ & $\mathbf{1 7 5}$ & $\mathbf{1 . 9 2 5}$
\end{tabular}

Tabel 2. Luas Lahan Kritis di DAS Widas pada 2009. Sumber: diolah dari data Pemerintah Kabupaten Nganjuk, Potret Kondisi Sumber Daya Air Kabupaten Nganjuk, 2011:12.

Tabel 2 menunjukkan kondisi lahan kritis di daerah Widas hanya menyisakan lahan yang meliputi wilayah Kecamatan Gondang, Rejoso, Bagor, Wilangan, Lengkong, dan Jatikalen. Adapun luas lahan kritis tersebut hanya menyumbang sekitar $21 \%$ luas lahan kritis di Kabupaten Nganjuk. Kondisi ini berbeda dengan sebelum pembangunan yang menyumbang luas lahan kritis mencapai 54\%. "Pembangunan irigasi Widas juga telah memberikan dampak bagi peningkatan kualitas kesuburan tanah. Dari awalnya memanfaatkan lahan rawa sungai sebagai media penanaman kenaf, namun setelah pembangunan mulai berubah fungsi menjadi lahan sawah. Kondisi tersebut sebagian besar terjadi di Daerah Retardasi Sungai Widas yang disebabkan mulai teratasinya ancaman genangan air," ujar Prianto di Madiun pada 20 November 2019.

Pada 2010 genangan air kembali terjadi di Kabupaten Nganjuk yang disebabkan oleh banjir 25 tahunan Sungai Widas. Banjir tersebut telah

mengakibatkan terjadinya perluasan genangan air di beberapa wilayah. Adapun perluasan genangan air telah mengakibatkan tergenangnya lahan di Daerah Retardasi Sungai Ulo mencapai $3.541 .028 \mathrm{~m}^{3}$, dan Sungai Kedungsoko mencapai $6.327 .574 \mathrm{~m}^{3}$. Genangan air juga telah menimbulkan kerugian material cukup besar bagi kehidupan masyarakat di Daerah Retardasi muara Sungai Widas dengan luas genangan mencapai 13.689.072 $\mathrm{m}^{3}$ (Departemen Pekerjaan Umum 1985:V-1). Perluasan genangan air di daerah retardasi DAS Widas tidak lagi disebabkan oleh kondisi fisik Sungai Widas melainkan oleh kerusakan hutan di hulu sungai.

\section{SIMPULAN}

Kajian ini telah menunjukkan bahwa pembangunan irigasi Widas merupakan upaya yang dilakukan dalam mengatasi bencana hidrometeorologis berupa banjir dan kekeringan. Bencana tersebut telah menyebabkan kesulitan hidup yang sering membelit masyarakat dan rendahnya produksi pertanian di Kabupaten Nganjuk. Inilah yang menjadi faktor-faktor penting yang menyebabkan perlunya dilakukan pembangunan irigasi Widas. Proyek irigasi Widas dirancang mampu menjadi jalan keluar bagi problem lingkungan dan ekonomi pertanian kawasan Nganjuk.

Menurut Goldblatt, perubahan ekosistem berpotensi memunculkan dampak material dan sosial. Pembangunan irigasi Widas telah memberikan dampak bagi kondisi 
sosial-ekonomi dan lingkungan di Kabupaten Nganjuk. Dampak sosialekonomi berkaitan dengan perubahan pola tanam, peningkatan produksi pertanian, dan produksi pada sektor perikanan sungai. Adapun pada 2003 pembangunan irigasi Widas telah berhasil meningkatkan produksi ikan dari budi daya sungai mencapai $308.125 \mathrm{~kg}$. Pada periode 2004 sampai 2005 peningkatan produksi juga terjadi pada komoditas padi sebesar $2,97 \%$.

Dampak lingkungan pembangunan irigasi Widas hadir setidaknya dalam dua hal. Pertama, luas lahan kritis di DAS Widas berkurang secara tajam sebesar 91\% dengan meninggalkan 1.925 hektar lahan kritis tersisa. Kedua, wilayah Nganjuk yang rentan diterjang banjir juga berhasil dibebaskan dari ancaman bencana yang rutin melanda. Setelah tahun 2010 banjir yang terjadi di Kabupaten Nganjuk tidak lagi disebabkan oleh kondisi fisik Sungai Widas, melainkan karena kerusakan hutan di bagian hulu sungai yang berada di Gunung Wilis dan Pegunungan Kendeng. Pengalaman ini memberikan kearifan sejarah bahwa pembangunan jaringan irigasi dan pengendali banjir hanya akan bermanfaat dalam rentang waktu sesaat, apabila tidak dibarengi dengan upaya pelestarian ekosistem di sepanjang aliran dan daerah hulu sungai.

\section{E. UCAPAN TERIMA KASIH}

Penulis mengucapkan terima kasih kepada semua pihak yang telah mendukung pelaksanaan penelitian untuk tulisan ini, khususnya Program Studi Ilmu Sejarah Universitas Jember. Terima kasih juga disampaikan kepada reviewer tulisan ini atas kritik dan sarannya.

\section{DAFTAR SUMBER}

Abdoellah, Oekan S. 2017. Ekologi Manusia dan Pembangunan Berkelanjutan. Jakarta: Gramedia Pustaka Utama.

Anon. 1979. "Menengok Daerah Banjir di Kabupaten Nganjuk (1): Pokoknya Nyawa Selamat, Kata Mbok Tarminah." Kompas, Januari, 1.

Anon. 1983. "Menteri PU Akan Resmikan Beberapa Mesin Pompa Air di Nganjuk." Surabaya Post, Oktober, 26.

Anon. 1983. "Harga di Pasaran Nganjuk Kini Bisa Rp 180,00 per Kilogram." Surabaya Post, November, 10.

Badan Pusat Statistik Kabupaten Nganjuk. 2006. Nganjuk Dalam Angka 2005-2006. Nganjuk: Badan Pusat Statistik. 2009. Nganjuk Dalam Angka 2009. Nganjuk: Badan Pusat Statistik.

Berita Acara Pemeriksaan untuk Penerimaan Pekerjaan Tahap I No. PSAPB.10/BA-PN/97. 
Handep Jurnal Sejarah dan Budaya Vol. 4, No. 1, Desember 2020, hlm. 19-38

CV Inneco Wish. 2003. Dokumen Penawaran Pekerjaan Normalisasi Kali Widas dan Pembangunan Drain Outlet di Kabupaten Nganjuk.

Departemen Pekerjaan Umum Direktorat Jenderal Pengairan. 1976. Feasiblity Report on the Widas Irrigation Project by Brantas Multipurpose Project oleh PT Indra Karya Consulting Engineers.

.1979. Flood Report the Widas River Basin.

1985. Pelaksanaan Pekerjaan

Studi Pengukuran Kapasitas Genangan Dalam Rangka Pengembangan Widas Basin Final Report oleh PT Indra Karya Consulting Engineers.

1987. Proyek Pengembangan

Wilayah Kali Widas.

.1995. Proyek Pembinaan Teknis

Pembangunan dan Pengembangan

Waduk: Bendungan Besar di Indonesia.

Departemen Pekerjaan Umum Direktorat Jenderal Sumber Daya Air. 2008. Laporan Akhir Pekerjaan Studi Sistem Penanggulangan Banjir Kali Widas, Kabupaten Nganjuk oleh PT. Rama Sumber Teknik.

Djatileksono, Tumari. 1987. Equity Achievement in the Indonesian
Rice Economy. Yogyakarta: Gadjah Mada University Press.

Ertsen, Maurits Willem. 2005. Prescribing Perfection: Emergence of an Engineering Irrigation Design Approach in the Netherlands East Indies and its Legacy 1830-1990. Rotterdam: Optima Grafische Communicatie.

Fox, James J. 1997. "Lumbung Beras di Jawa Timur: Ekologi dan Konteks Sosial Produksi Sawah." Hlm. 167-218 dalam Dick, H.W., J.J. Fox dan J. Mackie. Pembangunan Yang Berimbang: Jawa Timur dalam Era Orde Baru. Jakarta: PT Gramedia.

Gable, Richard W. dan J. Fred Springer. 2019. Administering Agricultural Development in Asia: A Comparative Analysis of Four National Programs. New York: Routledge.

Goldblatt, David. 2015. Analisa Ekologi Kritis. Yogyakarta: Resist Book.

Harahap, Iswar Pangaloan, dan Angelia Utari Harahap. 2018. Nilai Kelembagaan Menjaga Hutan dan Air Untuk Irigasi. Medan: Puspantara.

Hayami, Y dan M. Kikuchi. 1987. Dilema Ekonomi Desa. Jakarta: Yayasan Obor.

Herlina, Nina. 2020. Metode Sejarah. Bandung: Satya Historika. 
Kaharuddin, Nanang H. 1988. "Upaya Mengentas Manusia dari Derita Banjir Lewat Proyek Widas." Surabaya Post, November, 17.

Kantor Sensus dan Statistik Provinsi Jawa Timur. 1971. Jawa Timur dalam Angka Tahun 1971. Surabaya: Badan Pusat Statistik.

Kasiyanti, Joko Nugroho, dan Heriyadi Dwijoyanto. 2012. Kajian Penanggulangan Banjir Kali Widas Kabupaten Nganjuk Provinsi Jawa Timur. Diunduh Juni, 2020 (https://fa.itb.ac.id/wpcontent/uploads/sites/8/2012/07/ 95010303-Kasiyanti.pdf).

Kuntowijoyo. 2005. Pengantar Ilmu Sejarah. Yogyakarta: Bentang Pustaka.

Mardiyah, Rodiatam. 2016. "Pembangunan Waduk Wonorejo, Kabupaten Tulungagung Tahun 1982-2002". Skripsi, Program Studi Ilmu Sejarah Fakultas Ilmu Budaya, Universitas Jember.

Nawiyanto. 2012. Pengantar Sejarah Lingkungan. Jember: Jember University Press.

2013. "The Politics of Food and Food Security during Indonesia's Old Order (19451955)." Lembaran Sejarah 10(1):60-73.

Nugraheni, Bella Suci dan Dyah Kumalasari. 2017. “Dampak Revolusi Hijau Bagi Masyarakat di
Kabupaten Magelang pada Tahun 1984-1989.” Risalah 4(4):531-550.

Nurhati, Indah, S. Ramdhaniati dan N. Zuraida. 2008. "Peranan dan Dominasi Varietas Unggul Baru dalam Peningkatan Produksi Padi di Jawa Barat." Buletin Plasma Nutfah 14(1):8-13.

Panuju, Dyah R., Kei Mizuno dan Bambang H. Trisasongko. 2013. "The dynamics of rice production in Indonesia 1961-2009." Journal of the Saudi Society of Agricultural Sciences 12:27-37.

Partasasmita, Ruhyat, et al. 2019. "Impact of the Green Revolution on the Gender's Role in Wet Rice Farming." Biodiversitas 20(1):2336.

Pemerintah Kabupaten Nganjuk. 2011. Potret Kondisi Sumber Daya Air Kabupaten Nganjuk.

Rahayu, Dwiti Winar, Ruslan Wirasoedarmo, dan Bambang Suharto. 2015. "Optimasi Pola Tanam di Daerah Irigasi Senggowar dan Widas." Jurnal Keteknikan Pertanian Tropis dan Biosistem 3(3):322.

Reksohadiprodjo, Iso dan Soedarsono Hadisapoetra. 1986. "Perubahan Kepadatan Penduduk dan Penghasilan Bahan Makanan (Padi) di Jawa dan Madura." Hlm. 324 dalam Sajogyo dan William L. Collier (penyunting). Budidaya 
Handep Jurnal Sejarah dan Budaya Vol. 4, No. 1, Desember 2020, hlm. 19-38

Padi di Jawa. Jakarta: PT Gramedia.

Santoso, Budi, A. Sastrosupadi. 1991. "Pengaruh Jarak Tanam per Lubang Terhadap Pertumbuhan dan Produksi Batang Kering Kenaf Hc. G4 di Lahan Kering." Laporan, Balai Penelitian Tanaman Tembakau dan Serat (Balittas).

Santoso, Budi, A. Sastrosupadi, dan T. Supriyadi. 2001. "Demplot Penerapan Paket Teknologi Tumpangsari Jagung dan Kenaf dan Jagung dan Yute di Lahan Bonorowo Nganjuk." Prosiding, Lokakarya Agribisnis Kenaf dan Sejenisnya.

Shiamah, Nur Lailatul. 2019. "Pengaruh Bendungan Wlingi terhadap Lingkungan dan Ekonomi Masyarakat di Sepanjang Saluran Irigasi Lodoyo Tulungagung Tahun 1970-1990". Skripsi, Program Studi Ilmu Sejarah Fakultas Ilmu Budaya, Universitas Jember.

Sindhunoto. Max Margiono. 1979. "Menengok Daerah Banjir di Kabupaten Nganjuk (2): Mengapa Tangkis yang Rawan Tidak Diperbaiki ?" Kompas, Januari, 10.

Sunarto, Dwi Adi, Deciyanto Soetopo, dan Sujak. 2009. "Hama Tanaman Kenaf dan Pengendaliannya". Monograf, Balai Penelitian Tanaman Tembakau dan Serat.
Tjondronegoro, S.M.P. 1990. "Revolusi Hijau dan Perubahan Sosial di Pedesaan Jawa.” Prisma, 2:1-14.

Varley, Robert C.G. 1993. Masalah dan Kebijakan Irigasi Pengalaman Indonesia. Jakarta: LP3ES.

Wawancara. Prianto. Madiun, 20 November 2019.

Wawancara. Agus Santoso. Madiun, 19 November 2019.

Wirosoedarmo, Ruslan. 2017. Irigasi Pertanian Bertekanan. Malang: UB Press.

Yulia, Desma. 2019. "Revolusi Hijau Kebijakan Ekonomi Pemerintah Bidang Pertanian di Kanagariyan Selayo Tahun 1974-1998." Historia 4(2):10-21 